\title{
HUBUNGAN PENDIDIKAN DAN KEMISKINAN: PENDEKATAN VARIABEL MEDIASI PENDAPATAN PER KAPITA
}

\author{
Sodik Dwi Purnomo ${ }^{1}$ \\ Istiqomah ${ }^{2}$ \\ Suharno $^{3}$ \\ Fakultas Ekonomi dan Bisnis Universitas Jenderal Soedirman, Jawa Tengah, \\ Indonesia ${ }^{1,2,3}$ \\ Email: sodikdwipurnomo@yahoo.com
}

\begin{abstract}
Previous researches shows that the relationship of education on poverty is negative and significant. Therefore, this study introduces the mediating variable income per capita to analyze the path of education on poverty. Research purposes is analyzing whether per capita income mediates the effect of education on poverty. The data used are secondary data in the Province of the Special Region of Yogyakarta in the period 2000-2018. This research method is path analysis. The results show that per capita income mediates the relationship of education on poverty in partial mediation. This finding implies the importance of improving the quality of human resources through education to reduce poverty.
\end{abstract}

Keywords: Education; Poverty; Income Per Capita.

\begin{abstract}
ABSTRAK
Studi empiris terdahulu menunjukkan hubungan pendidikan terhadap kemiskinan adalah berkorelsi negatif dan signifikan. Oleh karena itu, penelitian ini memperkenalkan variabel mediasi pendapatan per kapita untuk menganalisis jalur hubungan pendidikan terhadap kemiskinan. Tujuan penelitian adalah menguji apakah pendapatan per kapita memediasi pengaruh pendidikan terhadap kemiskinan. Data yang digunakan adalah data sekunder di Provinsi Daerah Istimewa Yogyakarta dalam kurun waktu 2000-2018. Metode yang digunakan dalam peneltian ini analisis path. Hasil penelitian menunjukkan bahwa pendapatan per kapita memediasi hubungan pendidikan terhadap kemiskinan secara partial mediation. Temuan tersebut mengindikasikan pentingnya meningkatkan kualitas sumber daya manusia melalui pendidikan agar dapat mengurangi kemiskinan.
\end{abstract}

Kata kunci: Pendidikan; Kemiskinan; Pendapatan Per Kapita. 


\section{PENDAHULUAN}

Menurut Ozughalu (2016) tantangan utama dalam pembangunan ekonomi suatu negara adalah penduduk miskin dan rentan akan kemiskinan. Instrumen kebijakan dalam mengurangi jumlah penduduk miskin masuk sebagai tujuan pertama dari tujuh belas tujuan dalam percapaian Suitainable Development Goals (SDG's) pada tahun 2030 (Todaro, 2008). Dengan demikian, kemiskinan merupakan masalah krusial dan harus mendapatkan perhatian khusus bagi semua negara serta harus segera ditangani lebih lanjut.

Kemiskinan merupakan persoalaan yang tidak hanya berdimensi ekonomi, tetapi juga budaya, sosial, politik, dan ideologi (Kuncoro, 2003). Kondisi kemiskinan secara keseluruhan ditandai dengan kerentanan ekonomi, keterisoliran, ketidakberdayaan, dan ketidakmampuan dalam menyampaikan masukan atau aspirasi dan kebutuhan. Berhubungan dengan sifat kemiskinan yang multidimensional, maka memberikan dampak yang cukup nyata dan signifikan dalam kehidupan bermasyarakat. Dampak tersebut antara lain (1) secara sosial ekonomi dapat menjadi tanggungan masyarakat, (2) merununnya tingkat produktivitas secara masyarakat, (3) secara umum akan menyebabkan menurunnya tingkat pastisipati masyarakat, (4) menurunnya ketenteraman dan ketertiban di dalam masyarakat, (5) rasa percaya masyarakat kepada birokrasi untuk memberikan pelayanan umum menurun, dan (6) akan terjadinya penurunan kualitas SDM yang akan datang (Kementerian Pekerjaan Umum dan Perumahan Rakyat, 2018). 
Dampak tersebut sangat menarik untuk diteliti, karena kemiskinan merupakan sebab dari permasalahan yang kompleks dalam kehidupan bermasyarakat.

Menurut Badan Pusat Statistik (2018) kemiskinan merupakan suatu kondisi dimana penduduk miskin tidak mampu memenuhi kebutuhan dasar (basic needs approach). Pengukuran tersebut mengukur penduduk miskin pada sisi pengeluaran atau konsumsi dasar baik dari sisi makanan maupun non makanan yang diukur dalam satuan rupiah per individu. Berbeda halnya pengukuran kemiskinan menurut World Bank (2016) dimana pengukuran kemiskinan dititik beratkan pada kemampuan daya beli masyarakat atau Purchasing Power Parity (PPP) apabila pengeluaran atau konsumsi masyarakat per kapita di bawah US\$1,25 atau US\$2 per hari maka tergolong dalam penduduk miskin.

Menurut data Badan Pusat Statistik (2018) jumlah penduduk miskin di Indonesia cenderung mengalami penurunan, hal tersebut menunjukkan bahwa adanya dampak positif dari program kemiskinan yang sudah diimplementasikan. Tetapi pada kenyataannya jumlah penduduk miskin masih tetap ada dan memberikan dampak yang negatif terhadap pembanguan nasional (Kriswandari, 2016). Menurut Badan Pusat Statistik (2018) jumlah penduduk miskin di Indonesia tersebar di 34 provinsi dimana secara persentase Pulau Papua memiliki persentase penduduk miskin tertinggi di Indonesia yaitu 20,88 persen jika dibandingkan dengan pulau lainnya (Sumatera 10,88; Jawa 9,87; Bali \& Nusa Tenggara 14,24; Kalimantan 9,40; dan Sulawesi 12,66 persen). Namun, secara jumlah Pulau Jawa 
memiliki jumlah penduduk miskin terbanyak di Indonesia. Tabel 1 menunjukkan persentase kemiskinan berdasarkan provinsi di Pulau Jawa pada tahun 2012 - 2018.

Tabel 1.

Persentase Kemiskinan Berdasarkan Provinsi di Pulau Jawa Tahun 2011-2018 (\%)

\begin{tabular}{|c|c|c|c|c|c|c|c|c|c|}
\hline \multirow{2}{*}{ No } & \multirow{2}{*}{ Provinsi } & \multicolumn{7}{|c|}{ Tahun } & \multirow[t]{2}{*}{$\underset{\wedge}{\text { Rata }}$} \\
\hline & & 2012 & 2013 & 2014 & 2015 & 2016 & 2017 & 2018 & \\
\hline 1 & DIY & & & & & & & & \\
\hline & & 15,23 & 14,78 & 14,04 & 13,22 & 12,69 & 11,97 & 13,99 & 15,97 \\
\hline 2 & $\begin{array}{l}\text { Jawa } \\
\text { Tengah }\end{array}$ & 15,50 & 14,02 & 13,45 & 13,23 & 12,62 & 11,26 & 13,61 & 15,16 \\
\hline 3 & & 12,64 & 12,35 & 12,31 & 11,95 & 11,48 & 10,92 & 11,98 & 12,24 \\
\hline 4 & $\begin{array}{l}\text { Jawa Barat } \\
\text { Banten }\end{array}$ & 9,57 & 9,31 & 9,55 & 8,86 & 8,27 & 7,35 & 8,99 & 9,99 \\
\hline 5 & & 5,82 & 5.43 & 5,83 & 5,39 & 5,52 & 5,25 & 5,57 & 5,78 \\
\hline 6 & DKI Jakarta & 3,63 & 4,00 & 3,77 & 3,75 & 3,76 & 3,56 & 3,74 & 3,69 \\
\hline
\end{tabular}

Sumber : Badan Pusat Statistik, 2019

DIY : Daerah Iastimewa Yogyakarta

DKI : Daerah Khusus Ibu Kota

Rata $^{\wedge}$ : Rata-Rata

Tabel 1 menunjukkan persentase kemiskinan berdasarkan povinsi di Pulau Jawa pada tahun 2012 - 2018. Secara rata-rata pada tahun tersebut Provinsi DIY menempati peringkat pertama dengan persentase penduduk miskin di Pulau jawa. Hal tersebut dikarenkan karakter penduduk miskin di Provinsi DIY ditandai dengan tingkat pendidikan yang rendah. Hal tersebut berdampak, kepada penduduk miskin yang semakin sulit mendapatkan lapangan perkerjaan (Saragih, 2014). disusul posisi kedua Jawa tengah dan pada urutan terbawah DKI. Peneliti memilih Provinsi DIY sebagai lokasi penelitian, hal tersebut dikarenakan prersentase penduduk miskin tertinggi di Pulau Jawa. 
Penanggulangan kemiskinan pada tingkat nasional dibentuk Tim Nasional Percepatan Penanggulangan Kemiskinan (TNP2K) yang digagas oleh Presiden Bambang Susilo Yudhoyono dengan mengeluarkan Peraturan Presiden Republik Indonesia Nomor 15 Tahun 2010 tentang Program Percepatan Penanggulangan Kemiskinan (Purnomo, 2019). Program tersebut sampai sekarang dilanjutkan oleh kepemimpinan Presiden Joko Widodo dengan mengeluarkan Peraturan Presiden Republik Indonesia Nomor 166 Tahun 2014 tentang Program Percepatan Penanggulangan Kemiskinan. Pada tahap selanjutnya pemerintah membentuk Tim Koordinasi Penanggulangan Kemiskinan (TKPK) di tingkat provinsi, kabupaten dan kota yang tugasnya adalah menganalisis, mengendalikan, merancang anggaran, dan mengendalikan program-program pengentasan kemiskinan. Dari upaya-upaya pengentasan kemiskinan tersebut diharapkan kemiskinan di Indonesia dapat ditekan, sehingga memberikan dampak yang positif bagi pembangunan nasional.

Menurut Susanto et al., (2018) kualitas SDM ditentukan pada semakin tingginya tingkat pendidikan. Semakin tinggi pendidikan diharapkan manusia akan lebih produktif, sehingga akan meningkatkan pendapatan dan tidak terjerat dalam lingkaran kemiskinan. Kualitas pendidikan suatu negara dapat diproksi pada Indeks Pembangunan Manusia (IPM). Grafik 1 menunjukkan IPM Provinsi DIY dalam kurun waktu 2010 - 2018 menempati peringkat kedua setelah DKI Jakarta, namun IPM Provinsi DIY lebih tinggi dari pada Indonesia. Hal tersebut dikarenakan kualitas pendidikan di Provinsi DIY cukup baik yang mendapatkan predikat sebagai kota pendidikan (Sidik, 2015). 


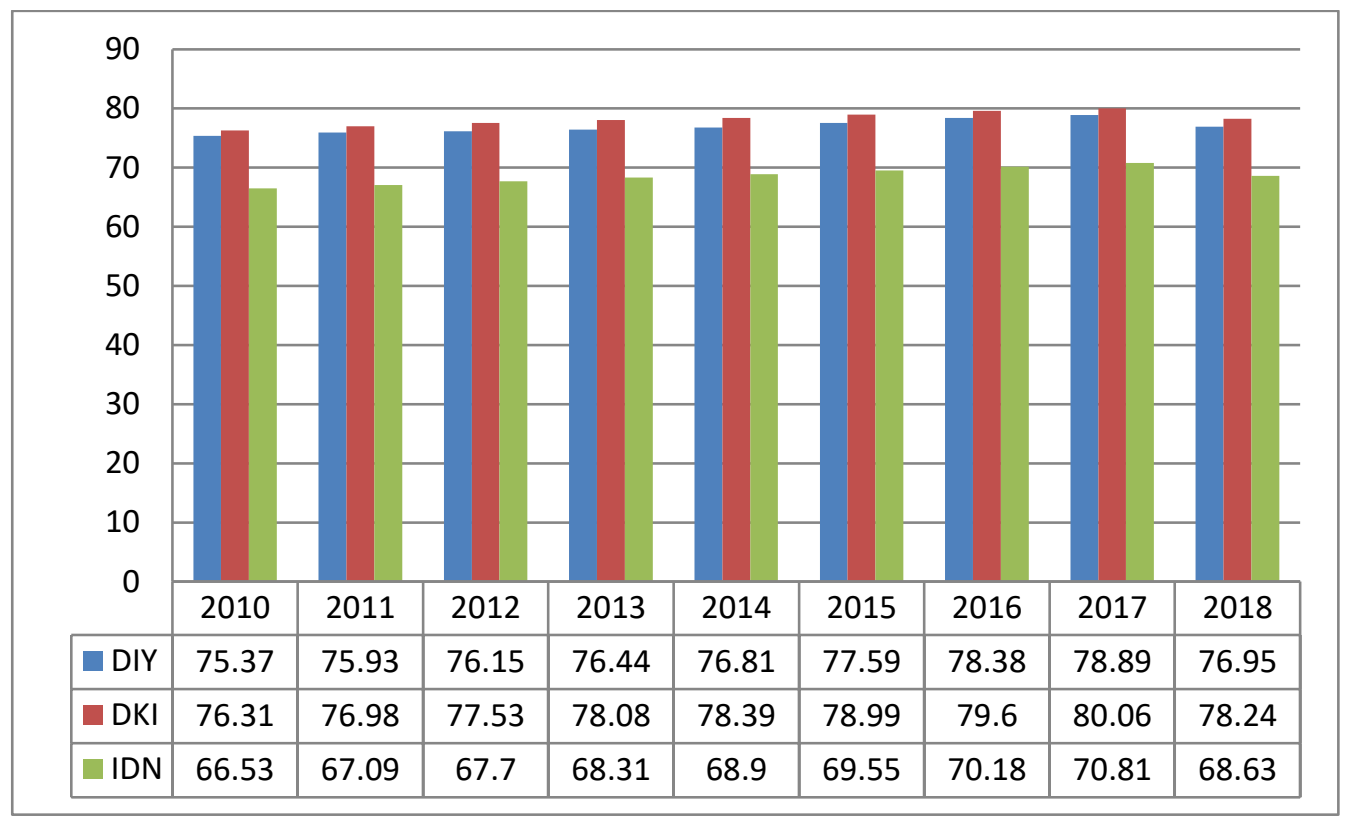

Sumber: Badan Pusat Statistik tahun 2018

Grafik 1.

Peringkat IPM Provinsi DIY dan Nasional Tahun 2018

Penelitian ini menguji analisis jalur hubungan antara pendidikan dan kemiskinan. Hal tersebut didasari bahwa pendidikan termasuk salah satu modal manusia untuk meningkatkan produktivitas dan pendapatan serta untuk meningkatkan kesejahteraan masyarakat. Selain itu, didukung oleh temuan (Awan et al., 2011; Ogundede et al., 2012; Colclough, 2012; Amalia, 2012; Tarabini \& Jacovkis, 2012; Merdekawati \& Budiantara, 201; Coley \& Baker, 2013; Mahsunah, 2013; Iswara \& Indrajaya, 2014; Zhang, 2014; Susanto et al., 2018; Bintang \& Woyanti, 2018; dan Azizah et al., 2018) yang menyatakan bahwa pendidikan berpengaruh linier negatif terhadap kemiskinan. Hal tersebut mengandung arti semakin tinggi tingkat pendidikan maka jumlah miskin semakin berkurang. Berdasarkan temuan tersebut peneliti menduga bahwa ada variabel intervening yang memediasi hubungan antara pendidikan dan kemiskinan. Peneliti menguji 
apakah pendapatan per kapita memediasi hubungan antara pendidikan dan kemiskinan. Logikanya salah satu penyebab kemiskinan adalah rendahnya tingkat pendidikan. Dengan demikian, untuk dapat mengentaskan kemiskinan, tingkat pendidikan masyarakat harus ditingkatkan, dengan demikian diharapkan masyarakat mampu meningkatkan produktivitas atau memperoleh pekerjaan yang layak, sehingga akan meningkatkan pendapatan dan kesejahteraan masyarakat akan lebih baik serta tidak terjerat dalam kemiskinan.

Berdasarkan urain di atas yang melatarbelakangi penelitian ini adalah tingkat kemiskinan di Provinsi Daerah Istimewa Yogyakarta menempati peringkat pertama di Pulau Jawa. Keterbaharuan dalam penelitian ini adalah memasukkan variabel pendapatan per kapita untuk menganalisis jalur hubungan pendidikan dengan kemiskinan yang belum pernah dilakukan, sehingga penelitian ini perlu untuk dilakukan. Dengan demikin tujuan dari penelitian ini adalah menganalisis apakah variabel pendapatan per kapita memediasi hubungan antara pendidikan dan kemiskinan di Provinsi DIY.

\section{METODE PENELITIAN}

Jenis penelitian ini adalah deskriptif dan kuantitatif. Penelitian deskriptif (descriptive research) adalah suatu metode penelitian yang ditujukkan untuk menggambarkan fenomena-fenomena yang ada, yang berlangsung saat ini atau saat yang lampau (Supranto, 2000). Penelitian kuantitatif adalah suatu jenis penelitian yang pada dasarnya menggunakan pendekatan deduktif-induktif (Sugiyono, 2013). Populasi dan sampel dalam penelitian ini adalah seluruh data times series dari rata- 
rata lama sekolah, kemiskinan, dan pendapatan per kapita dalam rentang waktu tahun 2000-2018. Dalam penelitian data sekunder diperoleh melalui studi pustaka yaitu dengan membaca buku-buku yang berkaitan dengan penelitian yang dilakukan, serta dari penelitian-penelitian sebelumnya. Selain itu, data juga diperoleh dari Badan Pusat Statistik (BPS), dan Badan Perencanaan dan Pembangunan Daerah (BAPPEDA) di Provinsi Daerah Istimewa Yogyakarta.

Adapun ukuran variabel dalam penelitian ini adalah 1) kemiskinan yaitu persentase penduduk yang berada di bawah garis kemiskinan yang diukur dalam satuan persentase, 2) pendidikan yaitu rata-rata lama sekolah yang ditempuh yang diukur dalam satuan tahun, 3) pendapatan per kapita didapatkan dari hasil pembagian pendapatan domestik regional bruto $\backslash$ dengan jumlah penduduk yang diukur dalam satuan rupiah di Provinsi Daerah Istimewa Yogyakarta dalam kurun waktu tahun 2000-2018 pemilihan periode tersebut didasarkan pada keterbatasan data. Pemilihan variabel tersebut didasarkan pada temuan bahwa pendidikan berpengaruh negatif terhadap kemiskinan seperti yang telah diuraikan pada pendahuluan di temuan penelitian terdahulu. Selain itu, ukuran kemiskinan secara makro ekonomi dapat diukur dengan pendapatan per kapita suatu daerah.

Teknik analisis data mengunakan regresi liner sederhana dan regresi linier berganda dangan bantuan software eviews. Pengunaan teknik analisis data tersebut didasarkan untuk mengetahui hubungan langsung variabel independen terhadap variabel dependent serta hubungan tidak langsung yang melalui variabel intervening (Panji dan Indrajaya, 2016). Pada penelitian ini menganalisis analisis 
jalur antara pendidikan dengan kemiskinan melalui variabel mediasi pendapatan per kapita. Berikut ini pola hubungan antara variabel secara langsung tanpa variabel mediasi dapat dilihat pada Gambar 1.

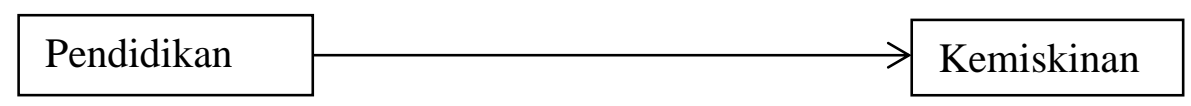

Gambar 1.

Model regresi tanpa variabel mediasi

Pola hubungan variabel melalui variabel mediasi antara pertumbuhan ekonomi dengan kemiskinan dapat dilihat pada Gambar 2.

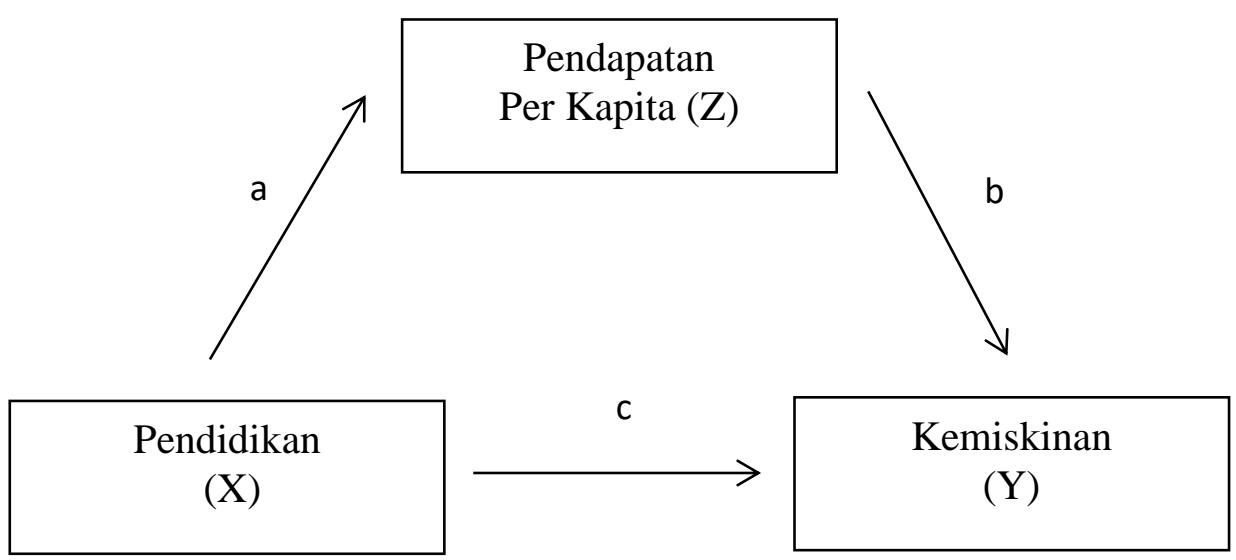

Gambar 2.

Model regresi melalui variabel mediasi.

Analisis variabel mediasi dilakukan dengan metode kausal step yang dikembangkan oleh Baron dan Kenny (1986). Adapun langkah-langkah dalam menggunakan Metode Kausal Step: 1). Membuat persamaan regresi variabel independen $(X)$ terhadap variabel dependen $(Y)$. 2). Membuat persamaan regresi variabel independen $(\mathrm{X})$ terhadap variabel mediasi (Z). 3). Membuat persamaan regresi variabel independen (X) terhadap variabel dependen (Y) dengan 
memasukkan variabel mediasi ukuran (Z). 4). Menarik kesimpulan apakah variabel mediasi tersebut memediasi secara penuh atau parsial (partial mediation).

Langkah-langkah tersebut dapat dilihat dalam bentuk persamaan sebagai berikut :

Persamaan I

$$
Y=\beta_{0}+\beta_{1} X_{1}+e
$$

Keterangan:

Y : Pendidikan diukur dalam satuan tahun

$\beta_{0,1} \quad$ : Koefisien regresi

$\mathrm{X}_{1} \quad$ : Kemiskinan diukur dalam satuan persentase

e : Error

Persamaan II

$$
Z=\beta_{0}+\beta_{1} X_{1}+e
$$

Keterangan:

$$
\begin{array}{ll}
\mathrm{Z} & : \text { Pendapatan per kapita } \\
\beta_{0,1} & : \text { Koefisien regresi } \\
\mathrm{X}_{1} & : \text { Kemiskinan } \\
e & : \text { Error }
\end{array}
$$

Persamaan III

$$
Y=\beta_{0}+\beta_{1} X_{1}+\beta_{2} Z_{2}+e
$$

Keterangan:

Y : Kemiskinan diukur dalam satuan persentase

$\beta_{0,1,2} \quad$ : Koefisien regresi

$\mathrm{X}_{1} \quad$ : Pendidikan diukur dalam satuan tahun

$\mathrm{Z}_{2} \quad$ : Pendapatan per kapita diukur dalam satuan rupiah

e : Error

Pada pengujian variabel $Z$ dinyatakan sebagai variabel mediasi atau intervening jika memenuhi kriteria sebagai berikut. 1). Jika pada persamaan I, 
variabel independen $(X)$ berpengaruh terhadap variabel dependen $(Y)$. 2). Jika pada persamaan II, variabel independen $(X)$ berpengaruh terhadap variabel yang diduga sebagai variabel mediasi (Z). 3). Jika pada persamaan III, variabel yang diduga sebagai variabel mediasi $(Z)$ berpengaruh terhadap variabel dependen $(Y)$.

Kriteria Pengujian (Suliyanto, 2011): 1). Variabel $Z$ dinyatakan sebagai variabel mediasi sempurna (perfect Mediation) jika setelah memasukkan variabel $Z$, pengaruh variabel $X$ terhadap $Y$ yang tadinya signifikan (sebelum memasukkan variabel Z) menjadi tidak signifikan setelah memasukkan variabel mediasi ke dalam model persamaan regresi. 2). Variabel $Z$ dinyatakan sebagai variabel mediasi parsial (partial mediation) jika setelah memasukkan variabel $Z$, pengaruh variabel $X$ terhadap $Y$ yang tadinya signifikan (sebelum memasukkan variabel $Z$ ) menjadi tetap signifikan setelah memasukkan variabel $Z$ ke dalam model persamaan regresi.

\section{HASIL DAN PEMBAHASAN}

Sejalan dengan penelitian terdahulu yang menunjukkan bahwa pendidikan berkorelasi negatif terhadap kemiskinan. Hal tersebut sejalan dengan temuan penelitian ini. Namun, penelitian ini masukkan variabel mediasi pendapatan per kapita untuk menganalisis jalur hubungan pendidikan dengan kemiskian yang akan diuraikan lebih lanjut.

Pada Model I menjelaskan hubungan langsung antara pendidikan (X) terhadap kemiskinan (Y), ringkasan output regresi dapat dilihat pada Tabel 2. 
Tabel 2.

Ringkasan Output Regresi Pendidikan (X) terhadap Kemiskinan (Y)

\begin{tabular}{lcc}
\hline \multicolumn{1}{c}{ Parameter } & Koefisien Regresi & Probabilitas \\
\hline Konstanta & 76,93081 & 0,0000 \\
$\mathrm{X}$ & $-6,943972$ & 0,0000 \\
\hline R-Squared & & 0,832998
\end{tabular}

Sumber: Data diolah, 2019

Tabel 2 maka dapat dituliskan persamaan penelitian Model I sebagai berikut. $\mathrm{Y}=76,93081-6,943972 \mathrm{X}$

Nilai koefisien pendidikan (X) sebesar -6,943972 dan apabila pendidikan naik 1 tahun maka dapat menurunkan kemiskinan sebesar $-6,943972$ persen (ceteris paribus). Selain itu, nilai probabilitas pendidikan (X) sebesar 0,0000 lebih kecil dari nilai tingkat signifikansi atau alpa sebesar 0,05 . Hal tersebut menunjukkan bahwa pada jalur Model I pendidikan (X) berpengaruh signifikan terhadap kemiskinan (Y).

Nilai $R$ square pada Model I sebesar 0,832998. Hal ini menunjukkan bahwa variasi perubahan naik turunnya kemiskinan dipengaruhi pendidikan (X) sebesar 83,29980 persen, sementara sisanya 16,7002 persen merupakan kontribusi dari variabel lain yang tidak dimasukan dalam penelitian. Dengan demikian diperoleh diagram jalur Model I yang ditunjukan pada Gambar 3.

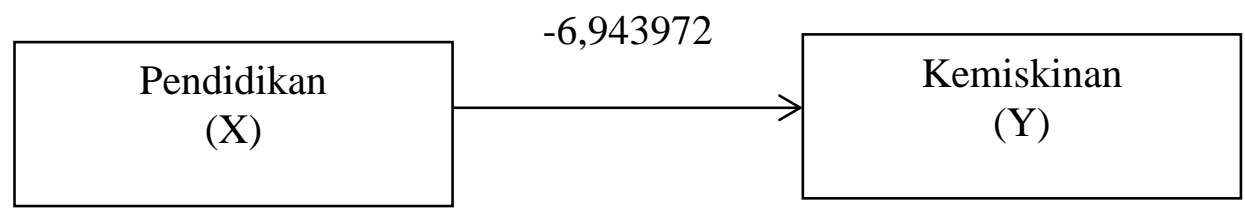

Sumber : Data diolah, 2019

Gambar 3.

Diagram Jalur Model I 
Pada Model II menjelaskan hubungan antara pendidikan (X) terhadap pendapatan per kapita $(Z)$, ringkasan ouput regresi dapat dilihat pada Tabel 3.

Tabel 3.

Ringkasan Output Regresi Pendidikan (X) terhadap

Pendapatan Per Kapita (Z)

\begin{tabular}{lcc}
\hline \multicolumn{1}{c}{ Parameter } & Koefisien Regresi & Probabilitas \\
\hline Konstanta & 7,291830 & 0,0025 \\
$\mathrm{X}$ & 2,667863 & 0,0023 \\
\hline R-Squared & & 0,497488 \\
\hline
\end{tabular}

Sumber: Data diolah, 2019

Tabel 3 maka dapat dituliskan persamaan penelitian Model II sebagai berikut ini.

$$
Z=7,291830+2,667863 X
$$

Nilai koefisien pendidikan (X) sebesar 2,667863 dan apabila pendidikan naik 1 tahun maka dapat meningkatan pendapatan per kapita sebesar 2,667863 persen (ceteris paribus). Selain itu, nilai probabilitas pendidikan (X) sebesar 0,0025 lebih kecil dari nilai tingkat signifikansi atau alpa sebesar 0,05. Hal tersebut menunjukkan bahwa pada jalur Model II pendidikan (X) berpengaruh signifikan terhadap pendapatan per kapita $(Z)$.

Nilai $R$ square pada Model I sebesar 0,497488. Hal ini menunjukkan bahwa variasi perubahan naik turunnya pendapatan per kapita dipengaruhi pendidikan (X) sebesar 49,7488 persen, sementara sisanya 50,2512 persen merupakan kontribusi dari variabel lain yang tidak dimasukkan dalam penelitian. Dengan demikian diperoleh diagram jalur Model II yang ditunjukan pada Gambar 4. 


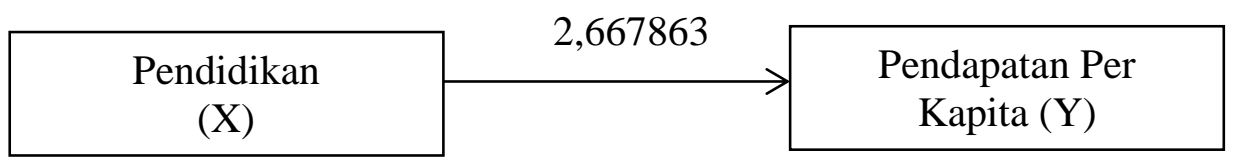

Sumber : Data diolah, 2019

Gambar 4.

Diagram Jalur Model II

Pada Model III menjelaskan hubungan antara pendidikan (X) dan pendapatan per kapita (Z) terhadap kemiskinan (Y) dapat dilihat pada Tabel 4.

Tabel 4.

Ringkasan Output Regresi Pendidikan (X) dan pendapatan

Per Kapita (Z) terhadap Kemiskinan (Y)

\begin{tabular}{lcc}
\hline \multicolumn{1}{c}{ Parameter } & Koefisien Regresi & Probabilitas \\
\hline Konstanta & 69,15398 & 0,0000 \\
X & $-4,098661$ & 0,0000 \\
Z & $-1,066513$ & 0,0000 \\
\hline$R$-Squared & & 0,9742668 \\
\hline
\end{tabular}

Sumber: Data diolah, 2019

Tabel 4 maka dapat dituliskan persamaan penelitian Model III sebagai berikut ini.

$$
\mathrm{Y}=69,15398-4,098661 \mathrm{X}-1,066513 Z
$$

Nilai koefisien pendidikan (X) sebesar -4,098661 dan apabila pendidikan naik 1 tahun maka dapat menurunkan kemiskinan sebesar $-6,943972$ persen ceteris paribus). Selain itu, nilai probabilitas pendidikan (X) sebesar 0,0000 lebih kecil dari nilai tingkat signifikansi atau alpa sebesar 0,05. Hal tersebut menunjukkan bahwa pada jalur Model III variabel pendidikan (X) berpengaruh signifikan terhadap kemiskinan (Y).

Nilai koefisien pendapatan per kapita (Z) sebesar -1,066513 dan apabila pendidikan naik 1 persen maka dapat menurunkan kemiskinan sebesar -1,066513 
persen (ceteris paribus). Selain itu, nilai probabilitas pendapatan per kapita (Z) sebesar 0,0000 lebih kecil dari nilai tingkat signifikansi atau alpa sebesar 0,05. Hal tersebut menunjukkan bahwa pada jalur Model III pendapatan per kapita (Z) berpengaruh signifikan terhadap kemiskinan (Y).

Nilai $R$ square Model III adalah sebesar 0,9742668. Hal ini menunjukkan variasi perubahan naik turunnya kemiskinan dipengaruhi oleh pendidikan $(\mathrm{X})$ dan pendapatan per kapita sebesar 97,42668 persen, sementara sisanya 2,57332 persen merupakan kontribusi dari variabel lain yang tidak dimasukan dalam penelitian. Dengan demikian diperoleh diagram jalur Model III yang ditunjukan pada Gambar 5.

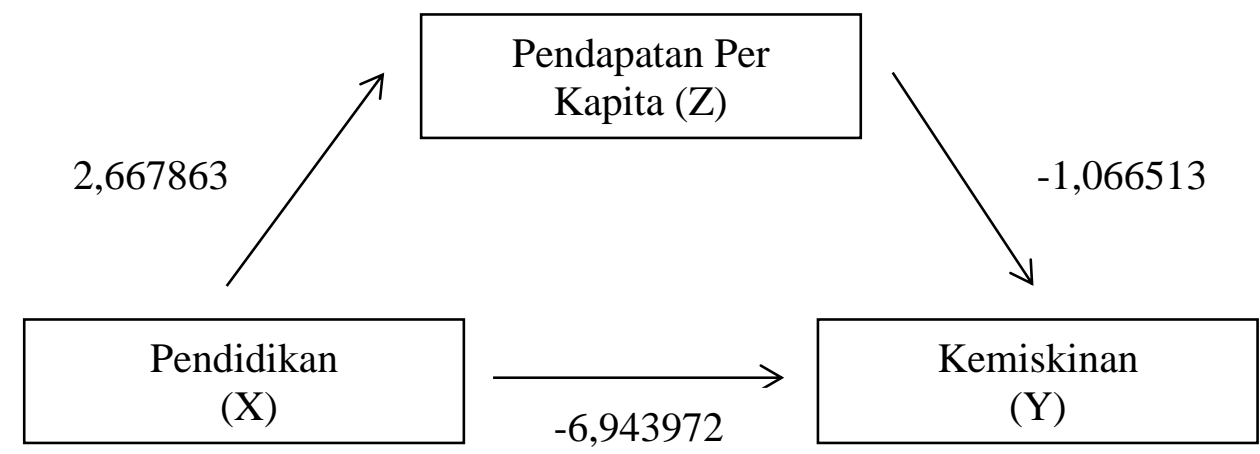

Sumber : Data diolah, 2019

Gambar 3. Diagram Jalur Model III

Mengacu kriteria pengujian hipotesis menunjukkan bahwa pendapatan per kapita secara partial mediation hubungan pendidikan terhadap kemiskinan. Investasi yang sangat penting untuk semua negara adalah pendidikan bagi semua penduduknya. Hal tersebut dikarenakan investasi di bidang pendidikan dapat menunjang kesuksesan perekonomian suatu negara dalam jangka panjang. Semakin 
baik tingkat pendidikan maka akan mempengaruhi kesejahteraan masyarakat (Azizah et al. 2018).

Pendidikan termasuk salah satu modal manusia. Investasi modal manusia (pendidikan, ketrampilan, kesehatan) mampu meningkatkan produktivitas dan pendapatan, sehingga kesejahteraan masyarakat juga ikut meningkat (Ogundede $e t$ al. 2012). Menurut penelitian sebelumnya (Tarabini \& Jacovkis, 2012; Zhang, 2014) pendidikan sebagai indikator pertama dalam mengentaskan kemiskinan. Hal ini dikarenakan dengan semakin tinggi tingkat pendidikan masyarakat maka semakin besar peluang dalam mendapatkan pekerjaan dan pendapatan yang layak.

Temuan Sulistyowati (2010) menemukan bahwa tingkat produktivitas dari tenaga kerja, peningkatan PDRB per kapita, physical capital, penyerapan tenga kerja, peningkatkan output daerah, peningkatan pengeluran sektor rumah tangga, penerimaan dan pengeluaran pemerintah, peningkatan investment, penurunan kemiskinan dan ketimpangan pendapatan, serta penurunan jumlah pengangguran itu semua merupakan pengaruh dari investasi di bidang pendidikan terhadap perekonomian suatu daerah. Investasi di sektor pendidikan akan menciptakan pertumbuahan ekonomi yang berkeadilan, artinya pertumbuhan ekonomi yang tinggi disertai dengan tingkat kesejahteraan masyarakat. Selain itu, investasi dibidang pendidikan menyebabkan ketimpangan pendapatan kan berkurang dan berjalan bersamaan dengan pertumbuhan ekonomi yang tinggi (tidak terjadi trade off antara pemerataan pendapatan dengan dengan pertumbuhan ekonomi). 
Todaro (2008) menjelaskan bahwa karakter sosial dan ekonomi dapat dipengaruhi oleh struktur pendidikan yang dianut di suatu darah atau negara. Menurut Sanz et al. (2017) jumlah penduduk miskin sangat dipengaruhi oleh pendidikan. Adanya kesenjangan dibidang pendidikan akan memberikan dampak langsung pada kesempatan untuk mendapatakan pekerjaan dan pendapatan yang tinggi. Temuan Hong \& Pandey (2007) dan Ataguba et al. (2013) menemukan bahwa dengan tingkat pendidikan yang semakin tinggi maka seseorang akan terhindar dari jeratan kemiskinan dan perekonomian suatu darah akan semakin baik.

Pertumbuhan ekonomi yang tinggi merupakan harapan semua negara. Namun permasalahan yang mendasar adalah bagaimana merumuskan instrumen kebijakan yang dapat diimplementasikan dalam memacu pertumbuhan ekonomi. Pertumbuhan ekonomi tersebut harus bersifat inklusif artinya dampak dari pertumbuhan ekonomi dapat dirasakan oleh semua lapisan masyarakat. Produk Domestik ragional Bruto (PDRB) ialah penjumlahan dari nilai barang dan jasa yang diproduksi oleh unit-unit produksi pada suatu daerah dan pada periode waktu tertentu (biasanya dalam rentang waktu satu tahun). Apabila ditinjau dari segi pendapatan ialah semua penerimaan/pendapatan yang didapatkan oleh pemilik faktor-faktor produksi yang berada disuatu wilayah dan dalam periode waktu tertentu (biasanya dalam rentang waktu satu tahun ). Apabila PDRB meningkat maka akan berdampak pada pendapatan per kapita suatu daerah (Sukirno, 2010).

Pendapatan per kapita merupakan salah satu indikator dalam mengukur kesejahteraan masyarakat disuatu daerah. Apabila pendapatan per kapita suatu 
daerah atau wilayah meningkat maka akan mempengaruhi daya beli dan kesejahteraan masyarakat akan semakin meningkat, serta akan berdampak langsung dalam mengurangi jumlah penduduk miskin. Menurut Norton (2002) semakin tinggi pertumbuhan ekonomi dan pendapatan per kapita memiliki makna bahwa suatu daerah memiliki kesempatan kerja yang banyak serta tingkat pendapatan yang lebih bagus, serta basis pemungutan pajak yang lebih besar yang memungkinkan pemerintah untuk berbuat lebih banyak bagi masyarakat miskin.

Temuan ini sejalan dengan teori lingkaran kemiskinan yang dikemukakan oleh Nurkse dalam Kuncoro (2003). Kemiskinan suatu daerah berpusat pada teori lingkaran kemiskinan ketika pendapatan masyarakat rendah yang diakibatkan oleh produktivitas yang rendah dan akan berdampak pada kemampuan menabung masyarakat yang rendah pula. Tabungan yang rendah akan menyebabkan pembentukan modal rendah yang menyebabkan kekurangan modal, dan dengan demikian produktivitas juga rendah dan seterusnya.

\section{SIMPULAN DAN SARAN}

Studi empiris terdahulu menunjukkan hubungan pendidikan terhadap kemiskinan adalah berkorelsi negatif dan signifikan. Hasil penelitian menunjukkan bahwa pendidikan berpengaruh langsung terhadap kemiskinan yang berkorelasi negatif dan signifikan. Selain itu, pendapatan per kapita memediasi hubungan pendidikan terhadap kemiskinan secara partial mediation. Temuan tersebut mengindikasikan pentingnya meningkatkan kualitas sumber daya manusia melalui pendidikan agar penduduk dapat meningkatkan produktivitas dan pendapatan, 
sehingga dapat mengurangi kemiskinan. Implikasi kebijakan adalah perlunya meningkatkan infrastruktur pendidikan meliputi peningkatan kualitas pengajar, pemberian beasiswa, dan menambah fasilitas pendidikan.

Keterbatasan penelitian ini hanya menganalisis pengaruh pendidikan dan kemiskinan dengan memasukan variabel mediasi pendapatan per kapita dengan sampel penelitian ditingkat provinsi. Saran untuk penelitian selanjutnya adalah bisa menganalisis pengaruh kesehatan, infrastruktur ekonomi terhadap kemiskinan dengan memasukan variabel mediasi. Selain itu, juga bisa mengambil sampel lokasi penelitian yang lebih luas seperti kepualauan atau negara dan bisa mengembangkan model penelitian ini lebih kompleks, dengan memasukan variabel dependent lebih dari satu variabel.

\section{REFERENSI}

Amalia, F. (2012). Pengaruh Pendidikan, Pengangguran dan Inflasi terhadap Tingkat Kemiskinan di Kawasan Timur Indonesia (KTI) Periode 20012010. Econosains Jurnal Online Ekonomi dan Pendidikan, 10(2): 158169. https://doi.org/10.21009/econosains.0102.02

Ataguba, J, E., Ichoku, H. E., \& Fonta, W. M. (2013). Multidimensional poverty assessment: applying the capability approach. International Journal of Social Economics, 40(4): 331-354. https://doi.org/10.1108/03068291311305017

Awan, M. S., Malik, N., Sarwar, H., \& Waqas, M. (2011). Impact of Education on Poverty Reduction. International Journal of Academic Research, 3(1): 659-664.

Azizah, E. W., Sudarti, S., \& Kusuma, H. (2018). Pengaruh Pendidikan, Pendapatan Per Kapita dan Jumlah Penduduk terhadap Kemiskinan di Provinsi Jawa Timur. Jurnal Ilmu Ekonomi, 2(1): 167-180.

Badan Pusat Statistik (2016). Statistik Indonesia Tahun 2016. Jakarta Pusat : Badan 
Pusat Statistik.

Badan Pusat Statistik (2018). Statistik Indonesia Tahun 2018. Jakarta Pusat : Badan Pusat Statistik.

Badan Pusat Statistik (2019). Statistik Indonesia Tahun 2016. Jakarta Pusat : Badan Pusat Statistik

Baron, R. M., \& Kenny, D. A. (1986). The moderator-mediator variable distinction in social psychological research: Conceptual, strategic, and statistical considerations. Journal of Personality and Social Psychology, 51(6), 1173-1182. doi: 10.1037//0022-3514.51.6.1173.

Bintang, A. B. M., \& Woyanti, N. (2018). Pengaruh PDRB, Pendidikan, Kesehatan, dan Pengangguran terhadap Tingkat Kemiskinan di Jawa Tengah (20112015). Media Ekonomi dan Manajemen, 33(1): 20-28. http://dx.doi.org/10.24856/mem.v33i1.563

Colclough, C. (2012). Education, Poverty and Development - Mapping their Interconnections. Comparative Education, 48 (2): 135-148. https://doi.org/10.1080/03050068.2011.608891

Coley, R. J., \& Baker, B. (2013). Poverty and Education: Finding the Way Forward. The ETS Center for Research on Human Capital and Education. Rutgers University. New Jersey.

Hong, P. Y. P., \& Pandey, S. (2007). Human capital as structural vulnerability of US poverty. Equal Opportunities International, 26(1): 18-43. https://doi.org/10.1108/02610150710726516

Iswara, I. M. A., \& Indrajaya, I, G, B. (2014). Pengaruh Pendapatan Asli Daerah, Pendapatan Per Kapita, dan Tingkat Pendidikan terhadap Tingkat Kemiskinan di Provinsi Bali Tahun 2006 - 2011. E-Jurnal Ekonomi Pembangunan, 3(11): 485-548.

Kementerian Pekerjaan Umum dan Perumahan Rakyat (2018). Rencana Strategis Kementerian Pekerjaan Umum Dan Perumahan Rakyat Tahun 2015 2019. Jakarta.

Kuncoro, M. (2003). Ekonomi Pembangunan: Teori, Masalah, dan Kebijakan. Yogyakarta: UPP AMP YKPN.

Kriswandari, E. (2018). Analisis Faktor-Faktor Kemiskinan dan Pemetaan Tingkat Kemiskinan Di Kabupaten Bantul Tahun 2011 Dan 2015. Tesis. FEB UGM. http://etd.repository.ugm.ac.id 
Mahsunah, D. (2013). Analisis Pengaruh Jumlah Penduduk, Pendidikan dan Pengangguran terhadap Kemiskinan di Jawa Timur. Jurnal Pendidikan Ekonomi (JUPE). 1(3): 1-17.

Merdekawati, I. P., \& Budiantara, I. N. (2013). Pemodelan Regresi Spline Truncated Multivariabel pada Faktor-Faktor yang Mempengaruhi Kemiskinan di Kabupaten/Kota Provinsi Jawa Tengah. Jurnal Sains Dan Seni ITS, 2(1): 19-24. DOI: 10.12962/j23373520.v2i1.3035

Norton, S. (2002). Economic Growth And Poverty: In Search of Trickle-Down. Cato Journal, 22(2): 263-27.

Ogundede, O. K. J., Akingbade, W. A., \& Akinlabi, H. B. (2012). Entrepreneurship Training and Education as Strategic Tools for Poverty Alleviation in Nigeria. American International Journal of Comtemporary Research, 2(1): 148-156.

Ozughalu, U. M. (2016). Relationship Between Household Food Poverty and Vulnerability to Food Poverty: Evidence from Nigeria. Social Indicators Research, 91: 113-124. https://doi.org/10.1007/s11205-014-0845-x

Purnomo, S. D. (2019). Determinan Kemiskinan di Provinsi Daerah Istimewa Yogyakarta, Jurnal Al-Amwal: Jurnal Ekonomi Dan Perbankan Syari'ah, 11 (1): 47-58. DOI: 10.24235/amwal.v11i1.4171

Sanz, R., Peris, J. A., \& Escámez, J. (2017). Higher education in the fight against poverty from the capabilities approach: The case of Spain. Journal of $\begin{array}{llll}\text { Innovation } \quad \text { \& } \quad \text { Knowledge, } & \text { 53-66. }\end{array}$ https://doi.org/10.1016/j.jik.2017.03.002

Saragih, J. P. (2014). Causes of Poverty and Yogyakarta Government Policy for Eradicating Poverty, JSEP, 6 (2): 139-155.

Sidik, F. (2015). Implementasi Program Jaminan Pendidikan Daerah di Kota Yogyakarta, Jurnal Kebijakan \& Administrasi Publik, 19(1): 27-44.

Sugiyono, S. (2013). Metode Penelitian Pendidikan Pendekatan Kuantitaif, Kualitatif, dan $R \& D$. Bandung: Alfabeta.

Sukirno, S. (2010). Makroekonomi. Teori Pengantar. Edisi Ketiga. PT. Raja Grasindo Perseda. Jakarta.

Sulistyowati, N., Harianto, H., Priyarsono, D. S., \& Tambunan, M. (2010). Dampak Investasi Pendidikan Terhadap Perekonomian Terhadap Kesejahteraan Masyarakat Kabupaten Dan Kota Di Jawa Tengah, Jurnal Organisasi dan Manajemen, 6(2): 158-170. 
Suliyanto, S. (2011). Ekonometrika Terapan: Teori Dan Aplikasi Dengan SPSS. Edisi 1. Yogyakarta: ANDI Yogyakarta.

Supranto, J. (2000). Teknik Sampling untuk Survey dan Eksperimen. Jakarta: Penerbit PT Rineka Cipta.

Susanto, E., Rochaida, E., \& Ulfah, Y. (2018). Pengaruh Inflasi dan Pendidikan terhadap Pengangguran dan Kemiskinan. INOVASI, 3(1): 19-27. http://dx.doi.org/10.29264/jinv.v13i1.2435

Tarabini, A., \& Jacovkis, J. (2012). The Poverty Reduction Strategy Papers: An Analysis of a Hegemonic link Between Education and Poverty. International Journal of Educational Development, 32(4): 507-516. https://doi.org/10.1016/j.ijedudev.2012.02.014

Todaro, M. P. (2008). Pembangunan Ekonomi (Jilid 1) (Edisi 9). Edisi Kesembilan Terjemahan Oleh Haris Munandar Dan Puji AL. Jakarta: Erlangga.

World Bank. (2016). Era Baru dalam Pengentasan Kemiskinan di Indonesia (ikhtisar). Jakarta: The World Bank Office Jakarta.

Zhang, H. (2014). The poverty Trap of education: Education-Poverty Connections in Western China. International Journal of Educational Development, 38(4): 47-58. https://doi.org/10.1016/j.ijedudev.2014.05.003 